\title{
Evaluation of hepatoprotective activity of stem bark of Pterocarpus marsupium Roxb.
}

\author{
K. L. Mankani' ${ }^{1}$, V. Krishna ${ }^{2}$, B. K. Manjunatha ${ }^{3}$, S. M. Vidya ${ }^{3}$, S. D. Jagadeesh Singh', Y. N. Manohara', \\ Anees-Ur Raheman ${ }^{3}$, K. R. Avinash ${ }^{3}$
}

Department of Pharmacology,
National College of Pharmacy,
Shimoga, Karnataka, India;
2Department of PG Studies and
Research in Biotechnology,
Kuvempu University,
Shankaraghatta, Karnataka,
India; ${ }^{3}$ Department of Botany,
S. R. N. M. College of Applied
Sciences, Shimoga, Karnataka,
India
Received: 3.6.2004
Revised: 16.10.2004
Accepted: 17.10.2004
Correspondence to:
V. Krishna
E-mail:

\begin{abstract}
Objective: To evaluate the hepatoprotective activity of Pterocarpus marsupium stem bark extracts against carbon tetrachloride $\left(\mathrm{CCl}_{4}\right)$-induced hepatotoxicity.

Materials and methods: Hepatotoxicity was induced in male Wistar rats by intraperitoneal injection of $\mathrm{CCl}_{4}(0.1 \mathrm{ml} / \mathrm{kg} /$ day for 10 days). Methanol and aqueous extracts of $P$. marsupium stem bark were administered to the experimental rats $(25 \mathrm{mg} / \mathrm{kg} /$ day, p.o. for 14 days $)$. The hepatoprotective effect of these extracts was evaluated by the assay of liver function biochemical parameters (total bilirubin, serum protein, alanine aminotransaminase, aspartate aminotransaminase, and alkaline phosphatase activities) and histopathological studies of the liver.

Results: In methanol extract-treated animals, the toxic effect of $\mathrm{CCl}_{4}$ was controlled significantly by restoration of the levels of serum bilirubin, protein and enzymes as compared to the normal and the standard drug silymarin-treated groups. Histology of the liver sections of the animals treated with the extracts showed the presence of normal hepatic cords, absence of necrosis and fatty infiltration, which further evidenced the hepatoprotective activity. Conclusion: Methanol extract of the stem bark of $P$. marsupium possesses significant hepatoprotective activity.
\end{abstract}

KEY WORDS: Red Kino; serum marker enzymes.

\section{Introduction}

Pterocarpus marsupium Roxb. (Papilionaceae) is a deciduous tree commonly distributed in forests of the western ghats of India. ${ }^{[1]}$ The plant is commonly known as Asanahm bijakah (Sanskrit), Red Kino tree (English) and Honne (Kannada). The gum obtained from the stem is used as astringent, in diarrhea and for toothache and the leaves are useful as external applications for boils, sores and skin diseases. $^{[2]}$ The flowers are used in fever, and the gum is locally applied in leucorrhoea and passive haemorrhage. ${ }^{[3]}$ The flavonoid constituents marsupin, pterosupin and liquiritigenin were isolated from the heart wood of the plant. The therapeutic effect of these constituents was reported to possess antihyperglycemic $^{[4]}$ and antihyperlipidemic activities. ${ }^{[5]}$ The aqueous extract of stem bark was found to reduce the blood glucose level in alloxan-induced diabetic rats. ${ }^{[6]}$ The ethnic groups residing in the vicinity of the Joldhal forest ranges of Karnataka are using the stem bark of this species in treating wounds, fever, stomachache, diabetes and jaundice. Literature reviews indicated that the hepatoprotective activity of these species has not been clinically evaluated so far. An active and safe drug is needed for the treatment of hepatitis. In view of this, the present study was aimed at evaluating the hepatoprotective activity of the stem bark of $P$. marsupium against carbon tetrachloride $\left(\mathrm{CCl}_{4}\right)$-induced hepatotoxicity in albino rats.

\section{Materials and methods}

The stem bark of $P$. marsupium was collected from Joldhal range forest, Davanagere, Karnataka. The plant was authenticated by comparing with the herbarium voucher specimen deposited at Kuvempu University Herbaria ${ }^{[7]}$ (FDD147) Shankaraghatta. The material was air dried under shade, powdered mechanically and stored in airtight containers. About $1 \mathrm{~kg}$ of the powdered material was boiled with $5 \mathrm{l}$ of distilled water for $30 \mathrm{~min}$ and filtered to obtain the aqueous extract. ${ }^{[8],[9]}$ The extract was concentrated under reduced pressure and finally dried using the water bath. Another $1 \mathrm{~kg}$ of the powdered material was subjected for soxhlation. It was refluxed with methanol for $48 \mathrm{~h}$ in batches of $250 \mathrm{~g}$ each. The extracts were pooled together and concentrated in vacuum using rotary flash evaporator (Buchi, Flawil, Switzerland).

Drug formulations

Oral suspensions containing $25 \mathrm{mg} / \mathrm{ml}$ of the methanol and aqueous extracts were prepared in $1 \% \mathrm{w} / \mathrm{v}$ gum tragacanth. 
Table 1

Effect of $P$. marsupium stem bark extracts on $\mathrm{CCl}_{4}$-induced hepatotoxicity in rats

\begin{tabular}{|c|c|c|c|c|c|c|}
\hline \multicolumn{2}{|c|}{ Group (n) } & Bilirubin & Protein & $A S T$ (IU/I) & $A L T(I U / I)$ & $A L P(I U / I)$ \\
\hline \multicolumn{2}{|l|}{ Control } & $0.49 \pm 0.03$ & $9.25 \pm 0.12$ & $51.07 \pm 0.61$ & $148.90 \pm 0.36$ & $173.61 \pm 2.57$ \\
\hline \multicolumn{2}{|c|}{$\mathrm{CCl}_{4}$ treated } & $2.22 \pm 0.13^{*}$ & $6.09 \pm 0.32^{*}$ & $1341.31 \pm 28.28^{*}$ & $2155.45 \pm 42.55^{*}$ & $404.10 \pm 18.11^{*}$ \\
\hline \multicolumn{2}{|c|}{$\mathrm{CCl}_{4}+$ Methanol extract } & $0.65 \pm 0.04^{* *}$ & $8.17 \pm 0.03^{* *}$ & $145.50 \pm 0.62^{* *}$ & $225.20 \pm 0.86^{* *}$ & $192.27 \pm 0.72^{* *}$ \\
\hline \multicolumn{2}{|c|}{$\mathrm{CCl}_{4}+$ Aqueous extract } & $0.91 \pm 0.05^{* *}$ & $7.27 \pm 0.05^{\star *}$ & $187.40 \pm 0.97^{\star *}$ & $282.51 \pm 1.02^{* *}$ & $217.17 \pm 1.32^{* *}$ \\
\hline One-way & $F$ & 162.46 & 57.82 & 1895.8 & 2086.6 & 152.45 \\
\hline
\end{tabular}

Values are expressed as mean \pm SEM. $\mathrm{n}=6$ rats in each group. ${ }^{*} P<0.01$ compared to control group; ${ }^{\star *} P<0.01$ compared to $\mathrm{CCl}$-treated group.

\section{Animals}

Male Wistar albino rats weighing 150-200 g were obtained from the National College of Pharmacy, Shimoga, Karnataka. They were maintained at standard housing conditions and fed with commercial diet (Hindustan Lever Ltd., Bangalore) and provided with water ad libitum during the experiment. The institutional animal ethical committee (Reg. No. 144/1999/ CPCSEA/SMG) permitted the study.

Evaluation of hepatoprotective activity

The acute toxicity studies were carried out as per stair case method. ${ }^{[10]}$ Fifty male rats were divided into five groups of 10 each and were administered with aliquot doses of the extracts orally $(100,150,200,250$ and $300 \mathrm{mg} / \mathrm{kg})$. Mortality was not noticed up to $200 \mathrm{mg} / \mathrm{kg}$, whereas, $100 \%$ mortality was noticed in the dose of $300 \mathrm{mg} / \mathrm{kg}$. The $\mathrm{LD}_{50}$ of the extracts was found to be $250 \mathrm{mg} / \mathrm{kg}$ body weight. One-tenth of this dose was selected as the therapeutic dose for the evaluation. ${ }^{[11]}$

Five groups of animals containing six each were used for the study. The animals from Group I served as the control and received the vehicle $1 \% \mathrm{w} / \mathrm{v}$ gum tragacanth at a dose of $1 \mathrm{ml} /$ $\mathrm{kg} /$ day of p.o. for 14 days. Groups II-V received $0.1 \mathrm{ml} / \mathrm{kg} /$ day i.p. of $\mathrm{CCl}_{4}$ (E-Merck, Mumbai, India) for 10 days. ${ }^{[12]}$ The standard drug Silymarin (Ranbaxy Lab. Dewas) was administered to Group III animals in the dose of $100 \mathrm{mg} / \mathrm{kg} /$ day p.o. for 14 days. While, Groups IV and V were treated with methanol extract and aqueous extract of $P$. marsupium in the dose of $25 \mathrm{mg} / \mathrm{kg} /$ day, p.o. (as per acute toxicity studies) for 14 days, respectively. The $\mathrm{CCl}_{4}$, silymarin and the extracts were administered concomitantly to the respective groups of animals.

Assessment of hepatoprotective activity

All the animals were killed on day 14 under light ether anaesthesia. The blood samples were collected separately by carotid bleeding into sterilized dry centrifuge tubes and allowed to coagulate for $30 \mathrm{~min}$ at $37^{\circ} \mathrm{C}$. The clear serum was separated at $2500 \mathrm{rpm}$ for $10 \mathrm{~min}$ and biochemical investigations were carried out to assess liver function viz., total bilirubin, ${ }^{113]}$ total protein, ${ }^{[14]}$ serum transaminases ${ }^{15]}$ and serum alkaline phosphatase ${ }^{[16]}$ (Raichem, San Diego, CA 921111203).

The results are expressed as mean \pm SEM of six animals from each group. The data were evaluated by one-way ANOVA followed by Tukey's multiple comparison test. $P$ values $\leq 0.01$ were considered statistically significant.

\section{Histopathology}

After draining the blood, liver samples were excised, washed with normal saline and processed separately for histological observations. Initially, the materials were fixed in $10 \%$ buffered neutral formalin for $48 \mathrm{~h}$ and then with bovine solution for $6 \mathrm{~h}$. Paraffin sections were taken at $5 \mathrm{~mm}$ thickness, processed in alcohol-xylene series and were stained with alum hematoxylin and eosin.. ${ }^{17]}$ The sections were examined microscopically for histopathological changes.

\section{Results}

The administration of $\mathrm{CCl}_{4}$ to the animals resulted in a marked increase in total bilirubin, serum amino transaminases (AST and ALT) and serum alkaline phosphatase activities. However, the serum total protein level was decreased. The toxic effect of $\mathrm{CCl}_{4}$ was controlled in the animals treated with the methanol and aqueous extracts by way of restoration of the levels of the liver function biochemistry similar to that of the standard drug silymarin (Table 1). Among the extract-

Figure 1. Section of the liver tissue of control rats showing normal histology, portal triad consisting of portal vein (V), portal artery (arrow), hepatic duct (arrowhead) (H \& E, $100 \mathrm{x}$ )

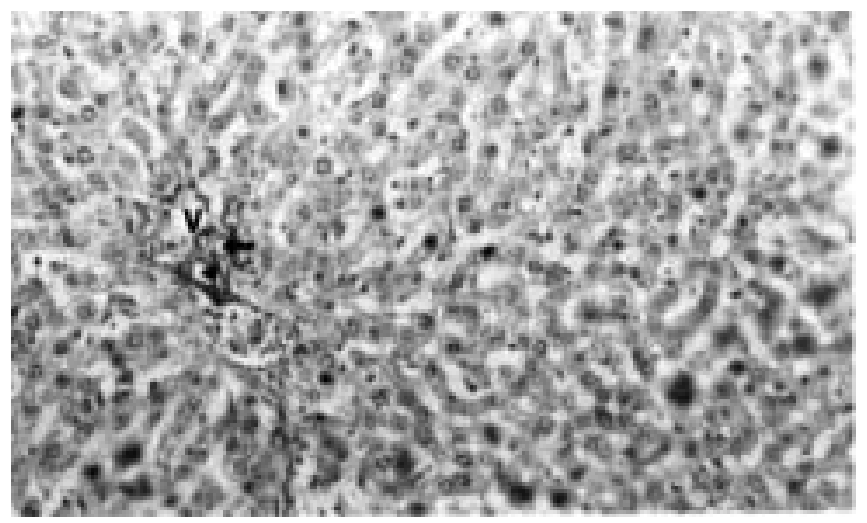


Figure 2. Section of the liver tissue of rats treated with $\mathrm{CCl}_{4}$ showing necrosis $(N)$ and fatty vacuole $(F)(H \& E, 100 x)$

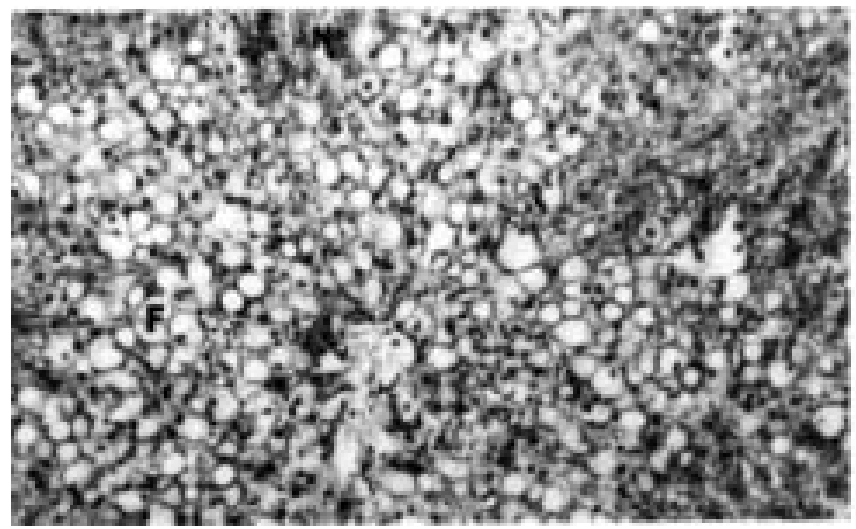

Figure 4. Section of the liver tissue of methanol extract-treated rat showing normal arrangements of hepatocytes around the central vein (V), absence of necrosis, fatty vacuoles (H \& E, $100 x)$

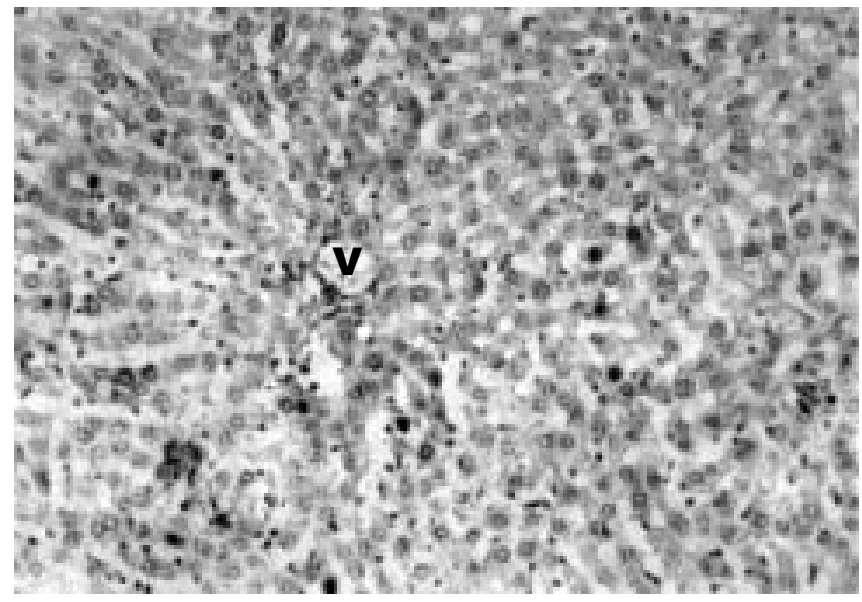

treated groups, significant hepatoprotective activity, was observed in those treated with methanol extract.

Histological profile of the control animals showed normal hepatocytes (Fig. 1). Group II animals exhibited intense centrilobular necrosis $(\mathrm{N})$, vacuolization $(\mathrm{F})$ and macrovesicular fatty change (Fig. 2). The sections of liver taken from the animals treated with standard drug silymarin showed the hepatic architecture, which was similar to that of control (Fig. 3 ). The animals treated with methanol extract exhibited significant liver protection against the toxicant as evident by the presence of normal hepatic cords, absence of necrosis and lesser fatty infiltration (Fig. 4). However, moderate accumulation of fatty lobules (Fig. 5) was noticed in the sections of animals treated with the aqueous extract.

\section{Discussion}

The $\mathrm{CCl}_{4}$ has been used as a tool to induce hepatotoxicity in experimental animals. ${ }^{[18],[19]}$ This toxic chemical caused peroxidative degradation in the adipose tissue resulting in fatty infiltration of the hepatocytes. The increase in the levels of
Figure 3. Section of the liver tissue of silymarin-treated rat showing normal hepatocytes, necrosis $(\mathrm{N})$, portal triad showing portal vein (V), portal artery (arrow), hepatic duct (arrowhead) (H \& E, $100 \mathrm{x}$ )

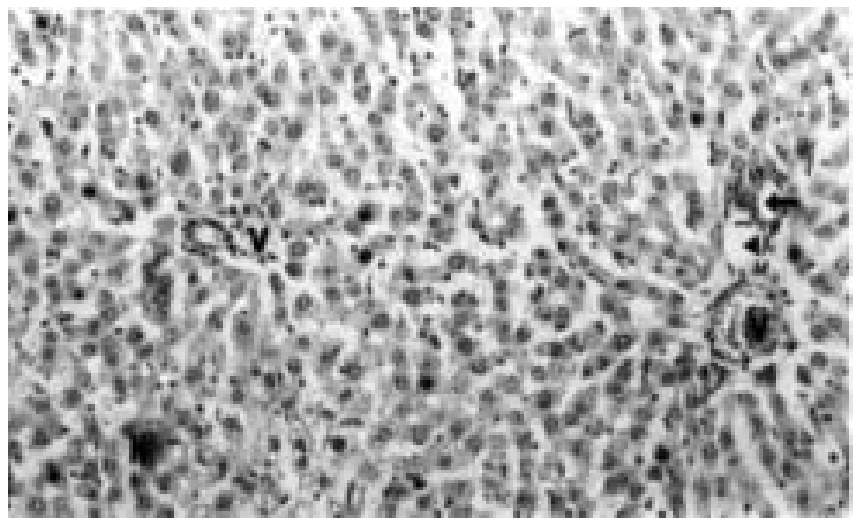

Figure 5. Section of the liver tissue of aqueous extract-treated rat showing arrangements of hepatocytes around the central vein (V), necrosis $(N)$, fatty vacuoles $(F)(H \& E, 100 x)$

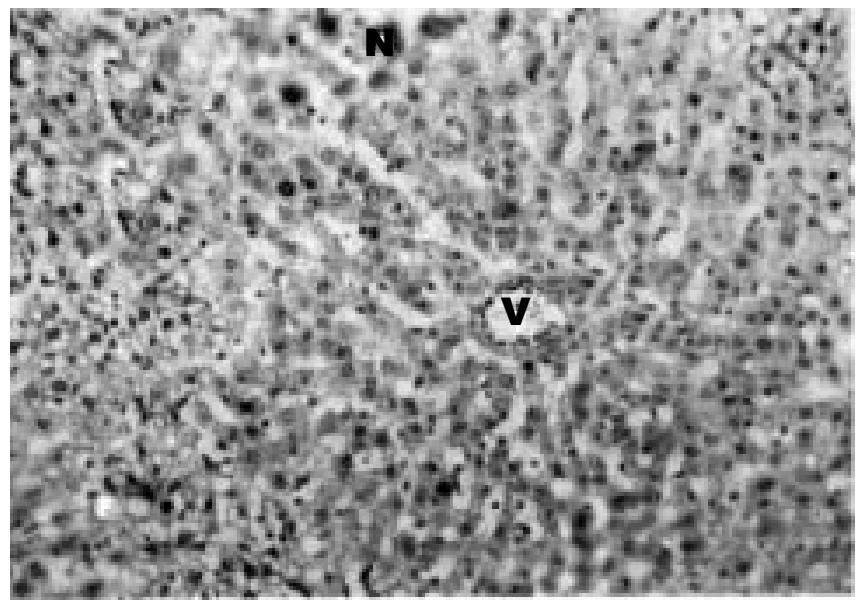

serum bilirubin reflected the depth of jaundice and the increase in transaminases and alkaline phosphatase was the clear indication of cellular leakage and loss of functional integrity of the cell membrane. ${ }^{20]}$

Administration of methanol extract and aqueous extract of $P$. marsupium stem bark showed significant hepatoprotective activity, which was comparable with the standard drug silymarin. The effect was more pronounced with methanol extract. Many phytochemical reports revealed that the methanolic extract of the plant was found to contain higher concentrations of flavonoids and glycosides. ${ }^{[21]}$ The qualitative phytochemical investigations on the methanolic extracts of $P$. marsupium also showed positive for flavonoids by ferric chloride, alkaline reagent and Shinoda tests. Further, it has been reported that the flavonoid constituents of the plant possess antioxidant properties ${ }^{[22]}$ and was found to be useful in the treatment of liver damage. ${ }^{23]}$ The administration of hepatoprotective drugs may induce the hepatocytes to resist the toxic effect of $\mathrm{CCl}_{4}$. The results indicate that the methanolic extract of $P$. marsupium has significant hepatoprotective 
activity. This may be probably due to the higher content of flavonoids. The earlier investigators ${ }^{[24]}$ have screened the hepatoprotective activity of the flavonoid compound, rutin, isolated from Artemisia scoparia, which is also claimed to have free radical scavenging and antilipid peroxidant activities against $\mathrm{CCl}_{4}$-induced hepatic toxicity. The isolation and characterization of the flavonoids from the stem bark of $P$. marsupium and screening of the pharmacological action against the liver damage is being investigated. In most of the developed and developing countries, the incidence of viral hepatitis is more so, the investigation for an efficient hepatoprotective drug from the natural resource is an urgent necessity.

\section{Acknowledgments}

The authors are grateful to Prof. B. Abdul Rahiman, Department Biotechnology, Kuvempu University and the Secretary, National Education Society, Shimoga, for providing all the necessary facilities to carry out this work.

\section{References}

1. Saldanha CJ. Flora of Karnataka. Vol. 1. Oxford: IBH Publishing Co.; 1984.

2. Chopra RN, Nayar SL, Chopra IC. Glossary of Indian medicinal plants. New Delhi: CSIR; 1956.

3. Pullaiah T. Medicinal plants of Andhra Pradesh (India). New Delhi: Regency Publications; 1999.

4. Manikam M, Ramanathan M, Jahromi MA, Chansouria JP, Ray AB. Antihyperglycemic activity of phenolics from Pterocarpus marsupium. J Nat Prod 1997;60:609-10.

5. Jahromi MA, Ray AB. Antihyperlipidemic effects of flavonoids from Pterocarpus marsupium. J Nat Prod 1993;56:989-94.

6. Vats V, Grover JK, Rathi SS. Evaluation of antihyperglycemic and hypoglycemic effect of Trigonella foenum-gracicum L., Ocimum sanctum L., and Pterocarpus marsupium L., in normal and alloxanized diabatic rats. J Ethnopharmacol 2002;79;95-100.

7. Manjunatha BK. Floristic composition of Davanagere District Karnataka. [Ph.D. Thesis]. Kuvempu University; 2002.
8. Cooper JW, Gunn C. Register of general pharmacy. Delhi: CBS Publisher and Distributor; 1987.

9. Rangari VD. Pharmacognosy and Phytochemistry. Part I. $1^{\text {st }}$ ed. Nashik: Career Publications; 2002.

10. Ghosh MN. Fundamentals of experimental pharmacology. $2^{\text {nd }}$ ed. Calcutta: Scientific Book Agency; 1984.

11. Jalalpure SS, Patil MB, Prakash NS, Hemalata K, Manvi FV. Hepatoprotective activity of fruits of Piper longum Linn. Indian J Pharm Sci 2003;65;360-6.

12. Jaiprakash B, Aland R, Karadi RV, Savadi RV, Hukkeri VI. Hepatoprotective activity of fruit pulp of Balanites aegyptiaca. Indian Drugs 2003;40;296-7.

13. Mallory HT, Evelyn EA. The determination of bilirubin with photoelectric colorimeter. J Biol Chem 1937;119:481-5.

14. Kingsley SR, Frankel SJ. The determination of serum total protein albumin and globulin by the biuret reaction. J Biol Chem 1939;128:131-7.

15. Reitman S, Frankel S. A Colorimetric method for the determination of serum glutamic oxoloacetic and glutamic pyruvic transaminase. Am J Clin Pathol 1957;28:56-63.

16. Bessey OA, Lowery DH, Brock MJ. A method for the rapid determination of alkaline phosphatase with five cubic meters of serum. J Biol Chem 1964;164:321-9.

17. Galighter AE, Koyloff EN. Essential of practical microtechnique. Philadelphia: Lea and Febiger; 1971.

18. Recnagel RO. Carbon tetrachloride hepatotoxicity statusquo and future prospects. Trends Pharmacol Sci 1983;4:129-31.

19. Okuno H, Hazama H, Muraze T, Shiozaki Someshima YT. Drug metabolizing activity in rats with chronic liver injury, induced by carbon tetrachloride relationship with the hydroxyproline content in liver. Jpn J Pharmacol 1986;41: 363-71.

20. Saraswat B, Visen PK, Patnaik GK, Dhawan BN. Anticholestic effect of picroliv, active hepatoprotective principle of Picrorhiza kurrooa, against carbon tetra chloride induced cholestatis. Indian J Exp Biol 1993;31:316-8.

21. Harboni JB. Phytochemical methods. $2^{\text {nd }}$ ed. 1979.

22. Hesham R. El- Seedi, Shgeru Nishiyama. Chemistry of Bioflavonoids. Indian J Parm Educ 2002;36:191-4.

23. Maurya R, Singh R, Deepak M, Handa SS, Yadav PP, Mishra PK. Constituents of Pterocarpus marsupium; an ayurvedic crude drug. Phytochemistry 2004;65: 915-20.

24. Khalid H Janbaz, Sheikh AS and Anwar HG. Protective effect of rutin on paracetamol and $\mathrm{CCl}$ induced hepatotoxicity in rodents. Fitoterapia 2002;73; $557-63$.

\title{
GenXPharm
}

\section{The newest e-group for the next generation pharmacologists}

\author{
Have a problem with your study design?
}

Looking for particular references?

Need a special chemical?

Want to know which statistical test to use?

Whatever your problem may be - you are not alone

Come share your thoughts, views and ideas with young pharmacologists all over India

Get help, information and support from your peers

Join GenXPharm - the e-group with pizzaz

This forum is for postgraduate students and research scholars only

\section{For further information please contact:}

\author{
Dr. S. Manikandan \\ Department of Pharmacology, JIPMER, Pondicherry-605 006. \\ E-mail: manikandan001@yahoo.com
}

